\title{
South Africa's multiple vulnerabilities, food security and livelihood options in the COVID-19 new order: An annotation
}

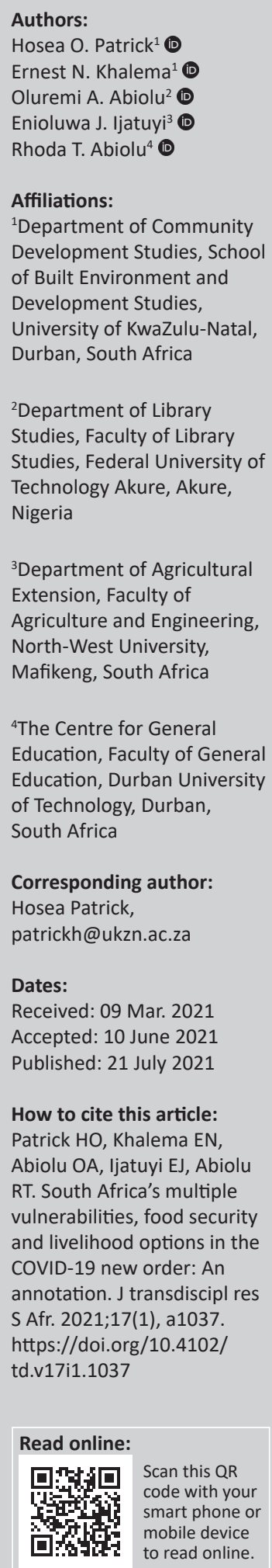

The advent of the COVID-19 pandemic and its crippling effects exacerbate many people's vulnerability to food security across the world, including Africa. This article offers an explorative discourse on the implication of COVID-19 pandemic for South Africa's food and livelihood security in the face of climate change. Using a scoping desktop review method, the article aims to provoke research and policy action and discourse on the subject matter. The article explores pre-and post-COVID-19 vulnerabilities in South Africa. It acknowledges the impact of climate change on food security and the situation of food security in South Africa pre-and post-COVID-19 pandemic. It then provides policy recommendations and expected outcomes to reconfigure the agricultural sector in the new sociopolitical and economic order necessitated by the pandemic. The article argues that reducing the stress posed by COVID-19 will require collaborative efforts and systemic thinking by stakeholders across all quarters. This will proffer workable solutions to mitigate the consequences of the COVID-19 pandemic on the food and livelihood options of rural dwellers in South Africa and their interconnectedness with the impact of climate change.

Keywords: COVID-19; food security; South Africa; climate change; livelihood options.

\section{Introduction}

The COVID-19 pandemic has raised serious policy concerns for food and livelihood security globally as indeed other human security sectors, particularly the economy and public health. ${ }^{1}$ The swiftness of spread, communicability and instantaneous strain of the pandemic on every facet of life and economy makes it a far-reaching global crisis. ${ }^{2,3}$ As of 18 February 2021, around 109 million people were reported to have contracted the virus, with over 2.4 million deaths globally. South Africa has recorded over 1.4 million confirmed cases and over 48000 deaths. ${ }^{4}$ The measures taken by governments (such as lockdown protocols, social distancing, etc.) to curtail the spread of this virus have had unintended consequences on almost all sectors of the economy, including the agricultural sector. ${ }^{5,6}$ The implication of these measures for communities, especially in the developing world in view of its many multiple vulnerabilities conditioned by weak coping mechanisms, is enormous and an issue of eminent policy concern. This is further exacerbated by poverty, government incapacities, weak infrastructure and institution and climate change impact on food and livelihood, among others. ${ }^{78}$

In Africa, the impact of climate change and other factors such as poverty, poor infrastructure and weak governmental capacities have been daunting issues prior to the COVID-19 pandemic. ${ }^{9}$ For instance, several studies have argued on the direct and indirect impact of climate change on agriculture and food security in Africa. ${ }^{10,11,12}$ The vulnerability of Africa to climate change impact (rainfall and temperature variations) is argued to be informed by weak coping strategies resulting from high poverty, incapacity of the government to provide basic amenities, population growth and over-dependence on climate-sensitive livelihood options, among others, leading to increased food and livelihood insecurity. ${ }^{1,8,9,11}$ The impact of these climate change variabilities on water availability coupled with these multiple exacerbators increases the vulnerability to food insecurity in Africa. This undoubtedly partly informed the United Nations Sustainable Development Goal (SDG) 2 aimed at ending hunger by 2030 while doubling agricultural productivity and income, especially for small-scale food producers. ${ }^{13}$

COVID-19 and its crippling effects exacerbate the vulnerabilities of many to food insecurity globally, including Africa. ${ }^{1}$ Although the multidimensional character of food security makes it

Copyright: ( 2021. The Authors. Licensee: AOSIS. This work is licensed under the Creative Commons Attribution License. 
difficult to define and measure, the Food and Agriculture Organization of the United Nations $(\mathrm{FAO})^{14}$ defined food security as:

... a situation that exists when all people have physical, social, and economic access to sufficient, safe and nutritious food that meets their dietary needs and food preferences for an active and healthy life. ${ }^{14}$ (p. 1)

This definition rests on food security pillars, namely, access, availability, utilisation and stability. ${ }^{15}$ With the overwhelming impact of COVID-19 on all facets of life, it is, therefore, no gainsaying that the impact of the COVID-19 pandemic will in no small measure aggravate the situation of human security (especially food, health and livelihood) while making the vulnerability of many to food and livelihood security even more daunting and worrisome. ${ }^{16}$ As the World Food Programme (WFP) ${ }^{17}$ and $\mathrm{FAO}^{5,18}$ opined, the concern for food security has been heightened since the outbreak of the pandemic. For instance, food prices have not only gone up but there were also cases of panic buying across South Africa during the early period of the pandemic. ${ }^{19}$ Given this, the knock-off effect of the measures taken on food security at the national and household levels, especially for the rural poor, has been enormous. It has increased the number of people under poverty and food insecurity because of the impact of the pandemic and measures taken on food access and affordability. ${ }^{17}$ This, therefore, provides the basis for evaluating the multiple vulnerabilities in Africa, and South Africa in particular, in the light of the emerging impacts of the COVID-19 pandemic.

In South Africa, the National Development Plan (NDP) presented an attainment date parallel to the SDG 22030 date of accomplishment in terms of hunger and poverty eradication. The NDP aims at ending poverty and reducing inequality in South Africa by harnessing the nation's human and material resources through leadership enhancement, inclusive economies and building human and material capacities and partnerships..$^{20,21}$ The attainment of these goals in less than 10 years seems blurred for many obvious emerging global issues and especially in the face of the ravaging COVID-19 pandemic. On these premises, this discourse builds the case around the varied levels of vulnerabilities that South Africa faces in tandem with existent challenges of food security and global concerns of climate change worsened by the reality of COVID-19.1,3 The article offers an explorative discourse on the implication of the COVID-19 pandemic for South Africa's food and livelihood security in the face of climate change and now the COVID19 's new order. The aim is to provoke research and policy action and discourse on the subject matter.

\section{Situation in Africa and South Africa}

On the African continent, the $\mathrm{FAO}^{22}$ estimated that about $23 \%$ of the Gross Domestic Product (GDP) and 60\% active population are in agriculture. The FAO further estimated that about 670 million are already faced with food insecurity out of which an estimated 250 million are considered food insecure and 512 million below the poverty line. The implication of this reality vis-à-vis the impact of climate change on agriculture and the attendant impact of COVID-19 pandemic on all spheres of livelihood make a significant population in Africa vulnerable to food and livelihood insecurity.

As indeed other developing countries in Africa, South Africa is not immune to the multidimensional impact of climate change on food security and livelihood. ${ }^{7,23,24}$ The South African Constitution (1996), Sections 26 and 27 1(b), speaks about every South African's right to sufficient food and water access. The implication of climate change on this crucial bill of rights, given the nation's vulnerability to the impact of climate change and its general aridity, is an issue of policy concern. ${ }^{8}$ These vulnerabilities are experienced at varying degrees primarily because of income inequality, historical imbalances and the issue of black tax, among many others. ${ }^{25}$

In South Africa, the growing impacts of COVID-19 coincide with the $1.4 \%$ retraction in the nation's economy coupled with the $7.7 \%$ decline in the 4th quarter of 2019 for the agricultural sector. ${ }^{26}$ This also falls under the backdrop of climate change's impact on food and livelihood security and the already stressed coping mechanisms available for rural communities. Statistics South Africa ${ }^{27}$ reported that despite the enormous efforts by the South African government to reduce hunger through social assistance amounting to about $3 \%$ of its GDP, as well as other interventions such as the national policy on food and nutrition security, integrated food security strategy (2002), agricultural policy action plan (2015-2019), integrated growth and development plan (2012) and strategic plan for the development of agriculture forestry and fisheries (2015-2020), over 3 million households still have no access to food because of the lack of economic means for food affordability.

Despite studies conducted on food insecurity prevalence in South Africa, ${ }^{28,29}$ the link between poverty, income, climate change and household food security is neither well understood nor well studied. Studies claimed that food insecurity is more prevalent in black-headed households, largely in rural areas..$^{28,29}$ Statistics South Africa ${ }^{29,26}$ highlighted that of the $39.26 \%$ South African population living in rural areas, $65 \%$ were identified as poor. Statistics South Africa ${ }^{27}$ posited that over $90.8 \%$ of households without food access were black Africans. Northern Cape and KwaZulu-Natal $(\mathrm{KZN})$ were flagged as the provinces with the highest proportion of households experiencing hunger. It also identified Limpopo, Eastern Cape and KZN as provinces with the highest proportion of rural poverty and households dependent on agricultural activities for food supply. Interestingly, these provinces are residents of the former homelands during the apartheid era. ${ }^{30,31}$ This, in many ways, buttresses the lopsidedness in the historical inequality evident in South Africa prior to 1994..$^{32,33}$

Judging from the data provided above, rural poverty is high in Free State, KZN and Eastern Cape largely because of the 
historical imbalances partly caused by the legacies of apartheid. Given this, food security is a mirage in most rural households in South Africa largely because of these historical effects of inequality resulting in widespread poverty. As Shisanya and Mafongoya opined, the country has one of the world's highest income inequality rates coupled with too high levels of absolute poverty. ${ }^{25}$ Similarly, April and Owusu-Sekyere argued that despite launching NDP as a poverty eradication policy drive in South Africa, there had been a steady increase in poverty, job loss and inequality in South Africa. ${ }^{20}$

World Data Lab (https://worldpoverty.io/map) estimated that an average of 16.2 million South Africans live in extreme poverty. Similarly, an average of 4.75 million South African households live below the poverty line, with over 14 million susceptible to food insecurity. ${ }^{34}$ There has been reportedly a gradual rise in the proportion of people living below the food poverty line of R441 per person per month since 2011. ${ }^{35}$ The Statistics South Africa ${ }^{36}$ report indicated a 2.8 million increase from 2011 to 2015 alone. ${ }^{36}$ These are largely because of low wages, unemployment and high dependency ratio, which are seemingly more prevalent in rural areas.

The combination of these multiple stress and threat multipliers in the event of the emerging impact of the COVID-19 pandemic on Africa and indeed South Africa begs for the need for policy and research considerations. As of January 2021, over 9 months since the global outbreak of COVID-19, in what we can safely refer to as 'post-COVID-19 premier hit (as a result of efforts at making vaccines available worldwide)', many are still battling with the immediate aftermath of the pandemic such as recession and job losses among others.

\section{Method}

The discourse is solely a desktop scoping review. A scoping review aims to provide an overview of emerging evidence from an array of sources. ${ }^{37,38}$ It is seen as a method of mapping and summarising evidence-based research to identify the priorities and gaps of a research phenomenon, to inform policy review and future research. ${ }^{7}$ By this, a synthesis of the literature on climate change, food security and COVID-19 with a focus on South Africa was carried out to provide a preliminary assessment of the scope and status of multiple vulnerabilities within the South African context.

To achieve this, a bibliometric analysis ${ }^{39}$ was used to identify relevant studies, data charting and collate summaries and reports. This led to gathering data and reviewing grey literature and online information between January 2010 and February 2021 using Google Scholar, International Scientific Indexing (ISI), ProQuest and Scopus search engines. The keywords used were 'climate change', 'food security' and 'COVID-19'. These keywords were then merged to include 'Africa' and 'South Africa', in particular. As Table 1 indicates, from about 302795 articles found on climate change between 2010 and 2021, only 7378 articles were on climate change and food security. Approximately, 885 articles were on climate change and COVID-19, while 489 articles were on food
TABLE 1: A summary of articles searched.

\begin{tabular}{ll}
\hline Keyword combination & Number of articles \\
\hline Climate change & 302795 \\
Climate change and food security & 7378 \\
Climate change and COVID-19 & 885 \\
Food security and COVID-19 & 489 \\
Climate change, food security and COVID-19 & 40 \\
Climate change, food security, COVID-19 and Africa & 3 \\
Climate change, food security, COVID-19 and South Africa & No document available \\
\hline
\end{tabular}

security and COVID-19. The combination of the three keywords 'climate change, food security and COVID-19' recorded 40 articles within the time frame sourced.

Interestingly, only three articles were related to 'climate change, food security, COVID-19 and Africa'. ${ }^{40,41,42}$ No data were recorded for South Africa within the confines of the keyword combinations searched. While this provides a clear rationale for this review within the context of South Africa, one may also argue that the emerging status of COVID-19 as a research endeavour may explain the dearth in literature for Africa, and South Africa in particular.

Using thematic content analysis, the data were triangulated with documents, monographs and organisational reviews and analysed for meaning and relevance. The discourse explores the nexus between climate change, food and livelihood security in the light of the impact of the COVID-19 global public health pandemic in South Africa. The rationale assesses South Africa's situation given the impact of climate change on food and livelihood security pre- and postCOVID-19 pandemic. It proffers policy recommendations and action plans to adopt a necessary coping mechanism by individuals, households, provinces and the nation while invoking research on the subject matter.

\section{Status before COVID-19}

Agriculture supports about $70 \%-80 \%$ of the entire African population, with approximately 4 million smallholder subsistence farmers in South Africa. ${ }^{25}$ This is seen as a major development priority in sub-Saharan Africa because of the proportion of people dependent on agriculture which is a climate-sensitive livelihood option. Statistics South Africa asserted that about 8.5 million people in South Africa are directly or indirectly dependent on agriculture for their livelihood. ${ }^{24}$ Turpie and Visser argued that the rural areas accounted for about $40 \%$ of South Africa's population. ${ }^{43}$ These areas are directly and indirectly dependent on natural resources (land and water) for their livelihood. Therefore, the impact of climate change on agricultural output can be expected to impact rural communities directly, given the level of poverty and inequality evident within these societies. ${ }^{8,44}$

Judging from the lopsided historical inequality prevalent in South Africa, ${ }^{30,31,32,33}$ for rural communities in Eastern Cape, Limpopo and KZN, the implication of climate change will not only affect agricultural productivity but also 
increase the propensity for food and livelihood insecurity. ${ }^{23}$ While South Africa is a secure food nation, about 1.7 million households and an estimated 6.8 million individuals are still affected by varying degrees of food insecurity. ${ }^{27}$ About $26.3 \%$ of South Africans live in households identified as food poor in the sense of being constrained economically or otherwise in securing sufficient food. ${ }^{45,46}$ About 28.3\% are at risk of food insecurity if their income or livelihood option is threatened in any way. ${ }^{47,48}$ For these reasons, it is arguable that food security is a mirage in most rural households in South Africa largely because of these historical effects of inequality that have cumulated in widespread poverty. Hence, the challenge of food insecurity is more probable among black African-headed households, largely in rural areas..$^{28,29}$

Statistics South Africa asserted that $55 \%$ of South Africa's population live below the national poverty line, with over 14 million susceptible to food insecurity. ${ }^{26}$ The report showed that KZN accounted for over $26 \%$ of poverty in South Africa, with over $56.3 \%$ of the population living in poverty. The report also identified KZN as one of the provinces with the highest proportion of rural poverty, hunger and households dependent on agricultural activities for food supply. Similarly, about 580000 households in KZN are food insecure. The need to explore the coping mechanism of rural households in the face of climate change, food and livelihood insecurity in the event of the enormous impact of the COVID-19 pandemic in South Africa becomes paramount. ${ }^{46,47,49}$

\section{COVID-19: Food security and nutrition risk}

Even though COVID-19 is an attacking respiratory illness, there is no direct relationship with food security. However, there is an indirect implication for food security as malnutrition increases the vulnerability of contracting the virus. ${ }^{50,51}$ There has been a range of conflicting and strengthening trends that have so far impacted food processes, food security and nutrition. This includes fragmentation of food supply chains, lack of jobs and livelihoods, expansion of inequalities, disruption of social welfare programmes, altered food environments and unequal food prices in localised settings. ${ }^{52,53}$

Fluctuations in food supply chains occurred globally as food system employees suffered high rates of sickness. ${ }^{52,54,55}$ This contributed to shutdowns and individual food processing facilities that resulted in a decrease in buying power for those who lost their incomes. ${ }^{1,49,52,56}$ It also had a significant effect on food security and nutrition, particularly for those who were already disadvantaged. ${ }^{49,56}$ Besides, considering the high degree of unevenness and complexity surrounding the virus and its development, there could be future risks to food security and nutrition, including the potential for reduced food output and development, depending on the magnitude and length of the pandemic and the efforts to combat it. ${ }^{52}$
The imminent and inevitable destruction of food production, supply chains and food supply in South Africa because of containment steps to curb the proliferation of COVID-19 poses immense food security threats for already disadvantaged people. ${ }^{1,49,57}$ As the COVID-19 pandemic spread, Statistics South Africa reported an increase in the number of no-income people in South Africa from 5.2\% before the national lockdown in March 2020 to 15.4\% (about $10.2 \%$ increase) after 6 weeks of lockdown. ${ }^{26}$ In the same report, about $11.4 \%$ indicated that they had experienced hunger during the lockdown. Within the agricultural sector, the unplanned and sudden restriction on movements led to a massive disruption in agricultural activities such as harvestings, processing and produce sales, among others. Small-scale farmers, especially those producing perishable stocks such as vegetables and fruits, suffered economic losses and shortage of supplies and a threat to household food security. The restriction on movement also led to labour loss as well as a decrease in production efficiency and capacity because of the disruption in the normal cycle of food supply. ${ }^{58}$ For instance, livestock and poultry markets were disrupted, leading to increased production costs and loss for farmers. In the face of these realities of COVID-19, people living within the agricultural production chain would be trapped in poverty should the situation continue. On a more macro level, the pandemic has enormous negative implications for consumer spending as the quarterly employment statistics (QES) survey also showed a job loss of about 671000 employees in all industries (approximately -6.6\%) in June 2020 as compared with the year before. ${ }^{26}$ This poses negative implication for the agriculture market and by inference increases individual and household food insecurity.

The immediate and long-term impact of the COVID-19 pandemic, especially for rural households solely dependent on agriculture as a means of livelihood and support, will be devastating. This includes the loss of households' income, less access to food gathering activities, closure of institutions that support food safety nets (such as food banks) and wastage of perishable foods such as vegetables, milk and fruits. This will imply untold hardship, especially for the rural poor. In South Africa, job losses, especially in the agricultural sector because of the pandemic, will alter the government's aim at increasing employment by a million in the agricultural sector by 2030 . The continuation of this crisis in the face of climate change's impact, among others, will imply a broader impact on the agricultural sector.

\section{Proposed policy recommendations and expected outcomes}

As we all strive to reshape our lives, the realisation of the COVID-19 new normal demands a reconfiguration of the agricultural sector so that it can function in a new world order necessitated by the pandemic. As Nwankpa ${ }^{59}$ posited, improved agricultural performance stimulates economic development and contributes to rural and urban hunger and poverty reduction. In this sense, agricultural growth is seen as pro-poor as it allows for greater participation of the 
poor in the growth process. The impact of climate change, and, more recently, the COVID-19 pandemic, makes agricultural performance, especially for the rural poor, a herculean task.

Despite the situation we find ourselves in, it is pertinent that the food supply chain continues to function unabated to avoid a food crisis at the national, local and household levels. As Mahendra ${ }^{60}$ and Arumugam and Kanagavalli ${ }^{61}$ observed, the 1943 Bengal famine led to about 3 million deaths because of a disruption in the food supply chain. To ensure continuous agricultural performance in the face of climate change and the unintended consequences of the COVID-19 pandemic, the following are recommended. It is pertinent to note that these recommendations are not exclusive. They are based on the authors' perceptions of possible alternatives in the mitigation and adaptation strategies necessary in the new 'COVID-19' world order:

- There is a need for the adoption of vertical and horizontal cooperative approaches by all stakeholders (national, provincial and municipal governments, community members and the public) in the development of coping mechanisms to food and livelihood insecurity in the face of the impact of climate change and the new order of COVID-19. To this effect, there is a need for public and private partnerships (PPPs) in extension, research and development in the agricultural sector. ${ }^{62,63,64}$

- There is also the need for further study and recognition of the place of small-scale agriculture in rural development, poverty alleviation and food security in South Africa.

- There is a need for proactiveness in government agencies' action in the agricultural sector rather than the typical reactionary tendencies of these agencies. ${ }^{8}$

- There is the need for a radical rethink of water management strategies and policies, which will allow for increased water harvesting and storage to improve agricultural yields at the provincial and municipal levels.

- Forecasting machinery is necessary to track food availability, pricing and access during and after the COVID-19 crisis. In this sense, the tracking system should be devised to monitor production based on food stock and yields and trade flow, pricing and availability in rural and urban areas.

- There is a need to introduce biotech seeds that are more resilient against climate change and pest threats.

- The need for a robust and well-structured skill and acquisition programme to empower the youth and unemployed segment of the population is key in the development agenda.

- There is a need for the re-examination of the strategic food reserve management and social safety nets to stabilise lives with food and cash on agricultural production and supply for rural poor households, especially in the face of the COVID-19 pandemic.

- There is a need to develop agencies and financial institutions to support rural poor households that are either already or on the verge of experiencing vulnerability to food and livelihood insecurity, especially in period crisis.
Whilst these measures and recommendations are not exclusive, they provide a basis for policy engagement. It is also interesting to note that the COVID-19 pandemic presents an opportunity for reforms in the agricultural sector in South Africa and a reconfiguration of the coping mechanism available for rural communities and households in the face of climate change, food and livelihood insecurity.

\section{Implementing actors}

The alleviation or reduction of the stress the COVID-19 pandemic will evoke for the South African economy, mostly for poor households in rural areas, requires collaborative and systemic thinking from all stakeholders. The implementing actors for the policy recommendations will include the following stakeholders. However, this is not exclusive:

- The national, provincial and municipal government: the government's role at all levels in the alleviation of poverty and hunger for the actualisation of food security and livelihood is crucial. The need for the government's conscious action at this trying time of the COVID-19 pandemic in the face of widespread poverty and the impact of climate change on the agricultural sector is even higher. While South Africa is food secure at the national level, the need for policy action and implementation to replicate the same strive, especially at the provincial and municipal levels and particularly in rural and relatively poor municipalities, is fundamental.

- Agencies of government: these are organisations set up by legislative or executive powers as government machinery set out to carry out oversight and/or administration of specific function of government. ${ }^{65,66}$ These agencies will be required to monitor and evaluate the policies implemented in the face of the pandemic's impact on the agricultural sector in order to alleviate hunger and ensure food and livelihood security for the rural poor. These agencies include the Agriculture and Rural Development across all provinces in the Republic of South Africa, the Department of Agriculture, Land Reform and Rural Development, Agric South Africa and Agribusiness Development Agency, among others.

- Community cooperatives: community agricultural cooperatives are crucial stakeholders in alleviating poverty and ensuring food security for rural households dependent on agriculture as a means of livelihood and food support. ${ }^{67,68,69}$ Their roles in providing support for farmers by the combination of collective human and capital resources are necessary coping mechanisms in the face of the COVID-19 pandemic.

- Research institutes: research institutes are also necessary stakeholders in implementing policy actions for coping during and after the pandemic. They are essential in evaluating and monitoring these policies to proffer better policy solutions during the implementation phase. These institutes include (but are not limited to) the 
Agricultural Research Council, Agricultural Research Council Vegetable and Ornamental Plants (ARC-VOPI), Council for Scientific and Industrial Research (CSIR) and Research Innovation and Sequencing Platforms, among others.

- Private corporations: the need for private corporations as crucial stakeholders cannot be overemphasised. They are expected to be involved in governmental efforts to alleviate food insecurity, especially in rural areas, as corporate social responsibility (CSR). ${ }^{70}$ In this sense because CSR is a responsibility of corporations to their host community, ${ }^{70,71}$ these corporations can help address urgent social and environmental challenges as it relates to the COVID-19 pandemic in their host community. The need for these actions in the COVID-19 era makes this even more remarkable.

- Individual and rural households: the alleviation of food insecurity and the creation of a sustainable livelihood option in the agricultural section in the face of climate change and the impact of the COVID-19 pandemic cannot be achieved without individuals and households themselves. There is a need for individual and household involvement as active partners rather than as passive participants in the policies necessary for a food secure rural household.

\section{Conclusion}

This article provided an exploratory discourse using a desktop scoping review. The rationale was to explore the degree of vulnerability the COVID-19 pandemic posed and still poses on food and livelihood security in South Africa, given other multiplier effects such as climate change, poverty and weak institutional and household coping mechanisms. The article acknowledged the impact of climate change on food security and the situation of food security in South Africa pre-and post-COVID-19 pandemic. It then provided policy recommendations and expected outcomes to reconfigure the agricultural sector in the new sociopolitical and economic order necessitated by the pandemic. The article argued that the reduction of the stress posed by COVID-19 would require collaborative efforts and systemic thinking by all stakeholders across all quarters. It thus proffered workable solutions to mitigate the consequences of the COVID-19 pandemic on food and livelihood options of rural dwellers in South Africa, as well as the interconnectedness of these with the impact of climate change.

\section{Acknowledgements \\ Competing interest}

The authors have declared that no competing interest exists.

\section{Authors' contributions}

H.O.P. conceptualised the idea and wrote the first draft. E.N.K. and O.A.A. reviewed the article. E.I.J. reviewed the second draft And R.T.A. reviewed the final draft of the article.

\section{Ethical considerations}

This article followed all ethical standards for research without direct contact with human or animal subjects.

\section{Funding information}

This research received no specific grant from any funding agency in the public, commercial or not-for-profit sectors.

\section{Data availability}

Data sharing is not applicable to this article as no new data were created or analysed in this study.

\section{Disclaimer}

The views and opinions expressed in this article are solely that of the authors and do not reflect the official policy or position of any affiliated agency of the authors.

\section{References}

1. Arndt C, Davies R, Gabriel S, et al. COVID-19 lockdowns, income distribution, and food security: An analysis for South Africa. Glob Food Sec. 2020;26:100410. https://doi.org/10.1016/j.gfs.2020.100410

2. Patrick HO, Abiolu RTI, Abiolu OA. Reflections on COVID-19 and the viability of curriculum adjustment and delivery options in the South African educational space. Transformation High Educ. 2021;6:1-9. https://doi.org/10.4102/the. v6i0.101

3. Schröder $M$, Bossert A, Kersting $M$, et al. COVID-19 in South Africa: Outbreak despite interventions. Sci Rep. 2021;11(1):1-9. https://doi.org/10.1038/s41598021-84487-0

4. WHO. Global research on coronavirus disease (COVID-19) [homepage on the Internet]. World Health Organization; 2020 [cited 2021 Feb 18]. Available from https://www.who.int/emergencies/diseases/novel-coronavirus-2019/globalresearch-on-novel-coronavirus-2019-ncov

5. Food and Agriculture Organisation. Migrant workers and the COVID-19 pandemic [homepage on the Internet]. 2020 [cited 2021 Feb 18]. Available from: http:// www.fao.org/3/ca8559en/CA8559EN.pdf

6. Schmidhuber J, Pound BQ. COVID-19: Channels of transmission to food and agriculture [homepage on the Internet]. 2020 [cited 2021 Feb 18]. Available from: of-transmission-to-food-and-agriculture-fao-policy-paper-2020/file.html

7. Hosea P, Khalema E. Scoping the nexus between climate change and watersecurity realities in rural South Africa. Town Reg Plann. 2020;77:18-30. https:// doi.org/10.18820/2415-0495/trp77i1.2

8. Patrick HO. Climate change, water security, and conflict potentials in South Africa: Assessing conflict and coping strategies in rural South Africa. In: Filho WL, Luetz
JM, Ayal DY editors. Handbook of climate change management: Research, leadership, transformation. Springer Nature, Cham, 2020; p. 1-8.

9. Waha K, Van Wijk MT, Fritz S, et al. Agricultural diversification as an important strategy for achieving food security in Africa. Glob Change Biol. 2018;24(8):3390-3400. https://doi.org/10.1111/gcb.14158

10. Mukiibi E. COVID-19 and the state of food security in Africa. Agr Hum Val. 2020;37(3):627-628. https://doi.org/10.1007/s10460-020-10079-9

11. Hall C, Dawson TP, Macdiarmid JI, Matthews RB, Smith P. The impact of population growth and climate change on food security in Africa: Looking ahead to 2050. Int J Agr Sustain. 2017;15(2):124-135. https://doi.org/10.1080/14735903.2017.1293929

12. Porter JR, Challinor AJ, Henriksen CB, Howden SM, Martre P, Smith P. Invited review: Intergovernmental panel on climate change, agriculture, and food - A case of shifting cultivation and history. Glob Change Biol. 2019;25(8):2518-2529. https://doi.org/10.1111/gcb.14700

13. United Nations Sustainable Development Group. Shared responsibility, global solidarity: Responding to the socio-economic impacts of COVID-19, United Nations [homepage on the Internet]. 2020 [cited $2021 \mathrm{Feb} 20$ ]; p. 1-26. Available Nations [homepage on the Internet]. 2020 [cited 2021 Feb 20]; p. 1-26. Available
from: https://www.un.org/sites/un2.un.org/files/sg_report_socio-economic_ impact_of_covid19.pdf

14. Food and Agricultural Organisation. Seeds, diversity, and development [homepage on the Internet]. 2020 [cited 2021 Feb 16]. Available from: http://www.fao.org/ economic/esa/seed2d/glossary/en/

15. Ericksen $P$, De Leeuw J, Thornton $P$, et al. Climate change in sub-Saharan Africa: Consequences and implications for the 'Future of Pastoralism in Africa: International Conference to Debate Research Findings and Policy Options', Addis Ababa, 21-23 March 2011. Nairobi, Kenya. https://hdl.handle.net/10568/3337. 
16. Ishiwatari M, Koike T, Hiroki K, Toda T, Katsube T. Managing disasters amid COVID-19 pandemic: Approaches of response to flood disasters. Prog Disaster Sci. 2020;6:100096. https://doi.org/10.1016/j.pdisas.2020.100096

17. Plan C. World food programme [homepage on the Internet]. 2020 [cited 2021 Feb 18]. Available from: https://dliic.dlab.or.tz/wp-content/uploads/2018/07/ CSP-Overview-June-2018.pdf

18. Food and Agriculture Organisation. COVID-19 pandemic - Impact on food and agriculture [homepage on the Internet]. 2020 [cited]. Available from: http://www. fao.org/2019-ncov/q-and-a/impact-on-food-and-agriculture/en/

19. Torero M. Without food, there can be no exit from the pandemic. Nature. 2020;580:588-589. https://doi.org/10.1038/d41586-020-01181-3

20. April YF, Owusu-Sekyere E. The way forward: Fast tracking the implementation of the NDP in South Africa: Lessons from South Korea. Pretoria: Africa Institute of South Africa, 2019; pp. 76-80.

21. National Planning Commission. National development plan (2030). Pretoria: Department of the Presedency of Republic of South Africa, 2010; p. 70.

22. Food and Agriculture Organisation. Africa regional overview of food security and nutrition. Accra: Food and Agriculture Organization, 2019.

23. Calzadilla A, Zhu T, Rehdanz K, Tol RS, Ringler C. Climate change and agriculture: Impacts and adaptation options in South Africa. Water Resour Econ. 2014;5:24-48. https://doi.org/10.1016/j.wre.2014.03.001

24. Mugambiwa SS, Tirivangasi HM. Climate change: A threat towards achieving 'sustainable development goal number two' (end hunger, achieve food security and improved nutrition and promote sustainable agriculture) in South Africa. Jàmbá: J Disaster Risk Stud. 2017;9(1):1-6. https://doi.org/10.4102/jamba. v9i1.350

25. Shisanya S, Mafongoya P. Adaptation to climate change and the impacts on household food security among rural farmers in uMzinyathi district of Kwazulu-
Natal, South Africa. Food Secur. 2016;8(3):597-608. https://doi.org/10.1007/ s12571-016-0569-7

26. Statistics South Africa. SA loses more than 600K formal sector jobs during COVID-19 lockdown [homepage on the Internet]. 2020 [cited 2021 Feb 16]. Available from: http://www.statssa.gov.za/? $p=13690$

27. Statistics South Africa. The extent of food security in South Africa [homepage on the Internet]. 2019 [cited 2021 Feb 18 ]. Available from: http://www.statssa.gov. $\mathrm{za} / \mathrm{p}=12135$.

28. Masipa TS. The impact of climate change on food security in South Africa: Current realities and challenges ahead. Jàmbá: J Disaster Risk Stud. 2017;9(1):1-7. https:// realities and challenges ahead. Jàmb
doi.org/10.4102/jamba.v9i1.411

29. Claasen $\mathrm{N}$, Lemke S. Strong ties, weak actors? Social networks and food security among farm workers in South Africa. Food Secur. 2019;11(2):417-430. https:// doi.org/10.1007/s12571-019-00902-5

30. Dinkelman T. Long-run health repercussions of drought shocks: Evidence from South African homelands. Econ J. 2017;127(604):1906-1939. https://doi. org/10.1111/ecoj.12361

31. Geyer $H$, Ngidi M, Mans G. Do social grants contribute to the jobless population growth in the former South African homelands?. Town Reg Plann. 2018;72:58-69. https://doi.org/10.18820/2415-0495/trp72i1.5

32. Kwenda P, Benhura M, Mudiriza G. Former homeland areas and unemployment in South Africa: A decomposition approach. IZA Discussion Papers, Bonn: Institute of South Africa: A decompositi
Labor Economics, 2020.

33. David A, Guilbert N, Hamaguchi N, et al. (Spatial) - Spatial poverty and inequality in South Africa: A municipality level analysis [homepage on the Internet]. 2018 [cited 2021 Jan 30]. Available from: http://www.opensaldru.uct.ac.za/ handle/11090/902\%0Ahttp://www.opensaldru.uct.ac.za/bitstream/ handle/11090/902/2018_221_Saldruwp.pdf?sequence=1

34. Ngema PZ, Sibanda M, Musemwa L. Household food security status and its determinants in Maphumulo local municipality, South Africa. Sustainability. 2018;10(9):3307. https://doi.org/10.3390/su10093307

35. Oluwatayo IB, Babalola MA. Asset ownership and income as drivers of household poverty in South Africa. I Dev Areas. 2020;54(3). https://doi.org/10.1353/ jda.2020.0028

36. Statistics South Africa. Poverty on the rise in South Africa [homepage on the Internet]. 2017 [cited 2021 Feb 23]. Available from: http://www.statssa.gov. $\mathrm{za} / \mathrm{p}=10334$

37. Peterson J, Pearce PF, Ferguson LA, Langford CA. Understanding scoping reviews: Definition, purpose, and process. J Am Assoc Nurse Pract. 2017;29(1):12-16. https://doi.org/10.1002/2327-6924.12380

38. Sucharew H, Macaluso M. Progress notes: Methods for research evidence synthesis: The scoping review approach. J Hosp Med. 2019;14(7):416-418. https://doi.org/10.12788/jhm.3248

39. Ienca M, Ferretti A, Hurst S, Puhan M, Lovis C, Vayena E. Considerations for ethics review of big data health research: A scoping review. PLOS one. 2018;13(10):e0204937. https://doi.org/10.1371/journal.pone.0204937

40. Ge J, Polhill J, Macdiarmid J, et al. Food and nutrition security under global trade: A relation-driven agent-based global trade model. R Soc Open Sci. 2021;8(1):1-47. https://doi.org/10.1098/rsos.201587

41. Huss $M$, Brander $M$, Kassie $M$, Ehlert $U$, Bernauer T. Improved storage mitigates vulnerability to food-supply shocks in smallholder agriculture during the COVID-19 pandemic. Glob Food Secur. 2021;28:100468. https://doi.org/10.1016/j. pandemic. Glob
gfs.2020.100468

42. Nchanji EB, Lutomia CK, Chirwa R, Templer N, Rubyogo JC, Onyango P. Immediate impacts of COVID-19 pandemic on bean value chain in selected countries in subSaharan Africa. Agr Syst. 2021;188:103034. https://doi.org/10.1016/j. agsy.2020.103034
43. Turpie J, Visser M. The impact of climate change on South Africa's rural areas. Johannesburg: Financial Fiscal Commission, 2013; pp. 100-160.

44. Zsiervogel G, New M, Archer van Garderen E, et al. Climate change impacts and adaptation in South Africa. Wiley Interdiscip Rev: Clim Change. 2014;5(5):605-620. https://doi.org/10.1002/wcc.295

45. Tesfamariam BY, Owusu-Sekyere E, Emmanuel D, Elizabeth TB. The impact of the homestead food garden programme on food security in South Africa. Food Secur. 2018;10(1):95-110. https://doi.org/10.1007/s12571-017-0756-1

46. Bikombo BG. Understanding household food insecurity and coping strategies of street traders in Durban. Doctoral dissertation, Pretoria: University of South Africa.

47. Ngidi ASC, Hendriks SL. Coping with food insecurity in rural south africa: The case of Jozini, Kwazulu-Natal. Mediterr J Soc Sci. 2014;5(25):278-289.

48. Walsh CM, Van Rooyen FC. Household food security and hunger in rural and urban communities in the Free State province, South Africa. Ecol Food Nutr. 2015;54(2):118-137. https://doi.org/10.1080/03670244.2014.964230

49. Fan E, Beitler JR, Brochard L, et al. COVID-19-associated acute respiratory distress syndrome: Is a different approach to management warranted?. Lancet Respi Med. 2020;8(8):816-821. https://doi.org/10.1016/S2213-2600(20)30304-0

50. Shah SJ, Barish PN, Prasad PA, et al. Clinical features, diagnostics, and outcomes of patients presenting with acute respiratory illness: A retrospective cohort study of patients with and without COVID-19. E Clin Med. 2020;27:100518. https://doi. org/10.1016/j.eclinm.2020.100518

51. Béné C. Resilience of local food systems and links to food security - A review of some important concepts in the context of COVID-19 and other shocks. Food Secur. 2020;12:805-822. https://doi.org/10.1007/s12571-020-01076-1

52. Laborde D, Martin W, Swinnen J, Vos R. COVID-19 risks to global food security. Science. 2020;369(6503):500-502. https://doi.org/10.1126/science.abc4765

53. Worstell J. Ecological resilience of food systems in response to the COVID-19 crisis. J Agr Food Syst Community Dev. 2020;9(3):1-8. https://doi.org/10.5304/ jafscd.2020.093.015

54. Hamouche S. COVID-19 and employees' mental health: Stressors, moderators and agenda for organizational actions. Emerald Open Res. 2020;2:15. https://doi. org/10.35241/emeraldopenres.13550.1

55. Chenarides L, Manfredo M, Richards TJ. COVID-19 and food supply chains. Appl Econ Perspect Policy. 2021;43(1):270-279. https://doi.org/10.1002/aepp.13085

56. Ben Hassen T, El Bilali H, S Allahyari M. Impact of COVID-19 on food behavior and consumption in Qatar. Sustainability. 2020;12(17):6973. https://doi.org/10.3390/ su12176973

57. Wegerif MC. 'Informal' food traders and food security: Experiences from the COVID-19 response in South Africa. Food Secur. 2020;12(4):797-800. https://doi. org/10.1007/s12571-020-01078-z

58. Corkery M. New and young farmer participation in agricultural planning in the township of Langley. Malaysian Palm Oil Counc. 2020;21(1):1-9.

59. Nwankpa N. Sustainable agricultural development in Nigeria: A way out of hunger and poverty. Eur J Sustain Dev. 2017;6(4):175. https://doi.org/10.14207/ ejsd.2017.v6n4p175

60. Yuvaraj M. COVID-19: Impact of agriculture in India. Vigyan Varta. 2020;1(3):25-27.

61. Arumugam DU, Kanagavalli DG. COVID-19: Impact of agriculture in India. Aegaeum J. 2020;8(5):480-488.

62. Mukherjee A, Maity A. Public-private partnership for convergence of extension services in Indian agriculture. Curr Sci. 2015;109(9):1557-1563.

63. Akimova YA, Kochetkova SA, Kovalenko EG, Zinina LI. Public-private partnership in agribusiness. Int Rev Manag Mark. 2016;6(4):814-822.

64. Rivera W. Privatization of extension systems. Agriculture Rural Development Discussion Paper [document on the Internet]. 2004 [cited]. Available from: / citations?view op=view citation \& continue $=/$ scholar?hl=es\&start=370\&as sdt $=0$, citations? $5 \&$ view_op=vilib=1\&scioq=tools\&citilm=1\&citation for view=PfIHHdUAAAAJ:LXmCCkuhh $5 \&$ scilib $=1 \&$ scioc
TsC\&hl=es\&oi=p

65. Arundel A, Bloch C, Ferguson B. Advancing innovation in the public sector: Aligning innovation measurement with policy goals. Res Policy. 2019;48(3):789-798. https://doi.org/10.1016/j.respol.2018.12.001

66. Mergel I. Open innovation in the public sector: Drivers and barriers for the adoption of Challenge.gov. Public Manag Rev. 2018;20(5):726-745. https://doi.or $\mathrm{g} / 10.1080 / 14719037.2017 .1320044$

67. White MM. Freedom's seeds: Collective agency and community resilience: A theoretical framework to understand agricultural resistance. J Agr Food Syst Community Dev. 2017;7(4):17-21.

68. Francesconi GN, Wouterse F. Building the managerial capital of agricultural cooperatives in Africa. Ann Public Coop Econ. 2019;90(1):141-159. https://doi. org/10.1111/apce.12218

69. Mojo D, Degefa T, Fischer C. The development of agricultural cooperatives in Ethiopia: History and a framework for future trajectory. Ethiop I Soc Sci Humanit. 2017;13(1):49-77. https://doi.org/10.4314/ejossah.v13i1.3

70. Crane A, Matten D. COVID-19 and the future of CSR research. J Manag Stud. 2021;58(1):278-282. https://doi.org/10.1111/joms.12642

71. $\mathrm{He} \mathrm{H}, \mathrm{Harris} L$. The impact of COVID-19 pandemic on corporate social responsibility and marketing philosophy. J Bus Res. 2020;116:176-182. https://doi. org/10.1016/j.jbusres.2020.05.030 